\title{
Journal of Awareness
}

Cilt / Volume 4, Sayı / Issue 3, 2019, pp. 377-384

E - ISSN: 2149-6544

URL: https://www.ratingacademy.com.tr/ojs/index.php/joa

DOİ: https://doi.org/10.26809/joa.4.029

Araştırma Makalesi / Research Article

\section{THE INFLUENCE OF ETHICS AND ISO STANDARDS ON THE EDUCATION PROCESS IN HIGHER EDUCATION}

\author{
Nikola VUKČEVIĆ * \& Dragiša VUKOTIĆ ** \\ * MA., Faculty of Arts and Communication, University of Donja Gorica, MONTENEGRO, \\ e-mail: nikola.vukcevic@udg.edu.me \\ ** PhD., Faculty of Philology, University of Donja Gorica, MONTENEGRO, \\ e-mail:dragisa.vukotic@udg.edu.me
}

\begin{abstract}
A review of education is provided through a prism of ethical principles and norms and through set ISO standards related to European mobility in the field of education. The historical dimension of the concept of ethics and ethical norms, which relies on the opinions of ancient philosophers Socrates and Plato, is primarily addressed, and the role of certain ethics in Modernism by Jeremy Bentham was also taken into consideration. Further attention is paid to the etymological roots of the concept of education.. For the third component of this research, ISO standards were adopted in the context of channeling experiences of practical use of the ethics of educators. A matrix, which deals with the synergy of the three concepts (education, ethics and ISO standards) has been set up, with the aim that with certain modifications, other than in Montenegrin, it functions in other regional or global scientific milieus.
\end{abstract}

Key words: Education, Ethics, University, ISO Standards, Montenegro. 


\section{INTRODUCTION}

The education process, widely understood as the development of mental and moral abilities primarily of young people, has been the subject of interest of thinkers during the development of human society. The problem is intriguing and there are no final solutions because the change and development of society results in new forms of education. The focus of our research is on the process of education in higher education which is analyzed through ethics and ethical norms. Also, we consider the impact of ISO standards on European mobility in the field of education and, therefore, we are trying to prove the mutual connection between education, ethics and the standards mentioned. The work, which is part of a wider research, sheds light only on one segment of this complex problem.

\section{ON ETHICS}

Ethics is a very broad and comprehensive concept. This omnipresent term, in its basis, has the moral and concepts of good and right. The theory of ethics should always contain two components, one that will determine what is good and the other one that will say what is right. When we read about ethics, we often find the concept of morality. Ethics and morals are so closely related that they are usually interchangeable. These two terms come from two different languages: ethics from the Greek word ethos (habit, custom character) (URL - 4, 2017), morality from the Latin words mos (custom), mores (conduct) (Juka 2006: 17). However, in order to develop this topic further, it is necessary to make a clear distinction between these two terms. The simplest definition would be that ethics is theory, but not any kind of theory, but the theory of morality; while morality is the praxis. Therefore, ethics is like philosophy and theory, a term broader in its meaning than morality, which is in a way a concrete form of human freedom.

The Greeks, as founders of this term, thought of ethics as a habit of their citizens, a custom that penetrated their culture and something that is an inevitable part of a human character. Ethics, a philosophical discipline, examines and explores the meaning and goals of morality. It sets the basic criteria for moral evaluation. The basic task of ethics is to introduce the individual to the components of morality, to show him true values he should accept, but also to criticize the existing moral practice. The subject of ethics, which is always dominant is, in fact, an activity that exclusively takes into account the importance of good and bad, deeply and thoroughly separating them - and that is morality. That is why ethics deals with the sources of morality, principles and norms of human behavior, in order to establish what is moral, which would ultimately be consolidated into the code of ethics (Aristotle 1988: 75).

Ethics is also one of the fundamental philosophical disciplines. Philosophical ethics does not deal with what something is, it deals with what something should be (Levinas 1969: 21). The issue of morality, which is the subject matter of ethics, is also the subjest of study of empirical sciences such as sociology and psychology of morality. Sociology examines the existing moral norms in different societies and cultures, and psychology deals with the psychological basis of morality.

Socrates, the ancient Greek philosopher, was particularly interested in ethics, and he is considered to be its founding father. Since Socrates did not leave any written tracks, Aristotle constantly mentions him in his works, emphasizing that Socrates was dealing with ethical matters. In ancient Greek society, politics was an integral part of almost every philosophy, and this is what we have in this case, with Socrates being interested in the moral aspect of a political life. In basis of Socrates' ethics lies the theory of the relationship of knowledge and virtue (Nails 2018). Therefore, he thought that a wise man who possesses knowledge of what is right should also do what is right (dr. Šarac 2014). In these terms, critics started from Aristotle, who said that the identification of knowledge and virtue ignores those irrational parts of the soul and moral weakness, which may make a man do something he knows is wrong. According to 
Socrates, the best thing that a man can do is the one that leads to his genuine benefits, in terms of his true happiness. Critical review of Aristotle refers to the fact that each person strives to achieve a true good for himself, but that does not mean that it will, if it is pleasant at the moment, lead to true happiness (Tomić 2016).

Socrates gives the highest ethical value to friendship. He primarily based friendship on the principle of usefulness, believing that it consists of mutual support. Socrates speaks about the ideal importance of friendship, as of a true friendship that can only exist among honest people, where true friends will do everything for each other (Čolaković 2010).

Eudaymonistic ethics is another viewpoint that emerged from Plato's philosophical thought. His ethics is focused on achieving the greatest good, which leads us to the development of man as a intellectual and moral being (URL - 5, 2017). Plato's good consists of pleasure and wisdom. That is why he advocated the rationalization of Socrates' thought, in other words, a man should moderate his mind, but this moderation must also exist in his sensual pleasures. Platos view was that a good life includes a good idea. This means that it is crucial that a person must be aware that this is lesser knowledge and that we must distinguish the world we perceive from the world we imagine. He pointed out that the material world is a copy of the empire of eternal ideas. Plato thought the greatest good is the one where a man tends to be similar to God as much as possible. Speaking about a man and his evil, the philosopher argues that a man does not do evil deliberately. He says that when someone chooses evil, he imagines this evil as something good and, despite his knowledge, chooses something that appears to be a short-term benefit. In these situations, Plato imposes a principle of moral responsibility, because a man allows his passions to blur his intellect and obscure his knowledge (Pavicevic 1967: 22-31).

The question has been asked: "What kind of good does ethics deal with?" In order to answer this question at least partially, it would be appropriate to try to find out what the ethics of norms is.

\subsection{Ethics of norms}

There is no doubt that the notion of ethics originally refers to some debates on ethical norms. Probably these norms tell us what something should be, and not what something is. If we look at the situation as it is, and keep to what is really true, then in this way we would express the real state, excluding any form of command, which leads us to the notion of indicia. In the second scenario, if the norm symbolizes what something should be, we command, we ask for something, we advise, and we are closer to the concept of imperative. Consequently, the ethics of norms clearly separates those norms that enter the circle of ethical and those that are out of that circle, that is those that have no real connection with the ethical (Driver 2009).

Basically, the ethics of norms, seen objectively, tries to justify ethical command, and one of the justifications are ethical directions called consequentialism. The most famous consequentialist ethics are hedonism and utilitarianism (URL - 6, 2016).

Hedonism comes from the Greek word hedone, meaning pleasure. The broadest meaning of this notion is that the greatest good a person should strive for is pleasure, whilst pain is the greatest evil that should be avoided. This ethical learning has its roots even in ancient Greek philosophy, where different views on hedonism were obvious. The philosophers of that time (on the one hand those of Cyrene as Eratosthenes and, on the other hand, the great thinker Epicurus) did not share same opinion on essential definition of pleasure. Those of Cyrene thought that pleasure was what we receive and feel, while Epicurus defined this notion as the absence of physical pain and mental uneasiness. In accordance with their way of thinking, the Cyrene philosophers emphasized bodily pleasure, which is better than mental, arguing that physical pain is worse than mental one. On the other hand, Epicurus advocated mental pleasure, which he considered loftier than physical (Weijers 2011). 
At the turn of the 18th century, Jeremy Bentham also thoroughly dealt with Hedonism. He considered that hedonism was rooted in the idea of a human nature which is based on feelings of pleasure and pain. Bentham expresses his thought at the beginning of his Introduction to the principles of morality and legislation:

"Nature has placed mankind under the governance of two sovereign masters, pain and pleasure. They alone point out what we ought to do and determine what we shall do; the standard of right and wrong, and the chain of causes and effects, are both fastened to their throne. They govern us in all we do, all we say, all we think; every effort we can make to throw off our subjection to pain and pleasure will only serve to demonstrate and confirm it. A man may claim to reject their rule but in reality he will remain subject to it. The principle of utility recognises this subjection, and makes it the basis of a system that aims to have the edifice of happiness built by the hands of reason and of law. Systems that try to question it deal in sounds instead of sense, in caprice instead of reason, in darkness instead of light" (Bentham 2007: 11).

Bentham based utilitarianism by introducing the principle of utility. This consequentialist ethics is strongly associated with hedonism, because, according to Bentham, utility is a synonym for happiness and joy. Happiness is the ultimate goal, that is enjoyment of pleasure and protection from pain. Therefore, utility is the principle that approves or does not approve a particular procedure, as this procedure makes happiness stronger or weaker. Under the notion of interesting feelings, Bentham defines pleasure and pain. He divides them into simple and complex, where the latter are generated by a combination of the former ones. However, it is clear that it is necessary to take into account the sensitivity of a person to the causes of pleasure and pain, which is expressed by the amount of sensitivity, and, again, this quantity depends on other circumstances - power, strength of mind and resistance (Bentham 2007: 27).

\section{EDUCATION AND ETHICS OF EDUCATORS}

If we tried to define the corpus of meaning of the term education, in short we might think of it as of the development of the mental, physical, and moral abilities of an individual. Of course, we are aware of the fact that education mainly refers to young people who are in the process of forming their attitudes and systems of values that can not be easily changed later. Firstly, it is necessary to look at the origin of the word itself. Etymologically, there are two tendencies. One refers to the fact that this word is derived from Latin "educare", which means "to raise or train". On the other hand, some think that education is derived from the verb "educere", which means "draw out" and "lead forward" (Djordjev 2009). We associate the latter meaning with teachers drawing out students from the state of ignorance into the condition of possessing knowledge. Regarding the fact that we are talking about a university lecturer, it is very important to consider his personality that affects students, as they are those who are still in the phase of being subject to external influences. What we find very important here is what actually the goal of the analysis in this paper is - the most important universal requirement of a university professor, the appearance and the content of his ethical codex.

Taking into consideration views on ethics in the previous chapter, we will explain the necessity of applying a set of ethical principles to the profession of a university professor. First of all, let us look at the eudamonistic ethics that Plato explained very clearly and concisely. He talks about the development of a man as a moral and intelligent being, that is, he sees moderation and rationality as unavoidable components of the mind of every individual, but he also puts an emhasis on them in terms of sensual pleasures. Therefore, a person that we call an intellectual today is formed. A university professor, in the capacity of an educator, must strive for this eudymmonistic approach. His intellectual highness must guide him to Plato's principle of moral responsibility, which means that he must not allow passions to disrupt his common sense and wisdom. 
Consequentialist ethics, hedonism and utilitarianism are potential elements of the ethical milieu of a university professor as an educator. First, we will refer to the necessity of hedonism. This concept is often in practice identified with the notion of egoism. However, in the basis of its more fundamental interpretation and study, it has an affirmative application. First of all, the fact that the hedonists do not attain their satisfaction at the expense of other people is in support of this, which is the basic assumption of egoism. The purpose of the hedonism is considered to be the most important purpose of human existence, and it is the pursuit of pleasure and the avoidance of any form of pain (URL - 2, 2019). In the case of a university professor, he should feel his profession and see it as a hedonistic part of his personality. Transferring knowledge and moral values to students for him should be a pleasurable experience, and the educator should continuously strive for it throughout his working life. Any additional professional or nonprofessional training for him should represent the pleasure and purpose of his existence and engaging in this work, not the pain that is the only remark that distances hedonism. Another consequentialist ethics is utilitarianism which represents the most significant normative - ethical theory in Modern. This theory was set by Bentham, and John Stuart Mill gave a great contribution to its existence. Mill described it as very significant in terms of a positive contribution to the advancement of science and the achievement of human well-being (URL 3, 2013). A clear definition of utilitarianism was provided by its creator, Jeremy Bentham, who expressed it as a principle of utility. Its role in the corpus of ethical elements of a university teacher is seen as inevitable and tightly connected with hedonism. Namely, the utility itself has an arbitrary role in approving or disapproving of a particular procedure, depending on whether this procedure makes our happiness stronger or weaker, which, according to Bentham, is a synonym for utility. The procedures a university professor carries out are the transfer of knowledge to the students, training them for the job market, influencing the formation of their system of values, etc. The question has been asked: "What is the professor's benefit of this?" If in the previous exposition about hedonism we found that dealing with this job is a form of pleasure, then the utility is the path which leads to our goal, that is, the accomplishment of this hedonistic part we are trying to achieve. Therefore, the usefulness of student education approves the transfer of knowledge process, so, in the end, this process will result in the increase of our happiness as an educator, that is, our satisfaction.

According to the previous presentation, we saw the necessity of applying two ethical lines in the capacity of the ethical structure of a university professor as someone who has the role of an educator in the educational system. First, the significance of Plato's eudymmonistic ethics, whose characteristics of mindfulness and rationality represent a significant precondition for dealing with this job is shown, and then consequentialist ethics, hedonism and utilitarianism are considered, which, if both are present, refresh the educator and give him a clearer picture of the need for control of irrational part of his personality. The application of the above potentially improves the quality of educational process in higher education.

\section{ETHICS AND ISO STANDARDS}

Montenegro, which is in the process of joining the European Union, must meet certain requirements regarding the acceptance of European standards. The fact is that an independent country, in this case, must have its own university, a theater, an airline company and in that innermost circle of necessary institutions, it must have the Institute for Standardization, which represents the link with the developed countries in areas of interest to the country. Montenegro, as the country that regained independence in 2006, in 2007 formed the ISME - Institute for Standardization of Montenegro. We will list some of the standards prescribed by the developed Western world (International Organization for Standardization) and wich are updated after a certain period of time with new versions: ISO 9001, ISO 14000, ISO 17025, ISO 18000, etc. It is imoprtant to point out that our interest sphere here is something that is related to standard 
MEST EN 15981:2012, which is called European Mobility in the Area of Education. This refers primarily to the mobility for professors which is manifested in different ways. They propose, and even require, longer stays at foreign universities where educators acquire not only knowledge, but also the spirit and manners of environments with a much longer tradition than ours. There are also common projects (Tempus, Erazmus, etc.) where, through joint work and projects, one is maturing intellectually and slowly, from a somewhat tribal comfortable approach, one becomes a part of the developed scientific world (URL - 1, 2017). Primarily, this standard creates a model that does not aim to collect a set of all information on mobility of teaching staff, but its scope is limited to the electronic representation of official and institutionally confirmed information about the progress of the participants in the educational process. These factual - experiential information can be exchanged in electronic form or through the mobility of teachers who, in the role of the representative, receive official institutional data (URL - 1, 2017). What is important here is to explore the opportunity to gather experiences from other scientific environments in the context of the setting of the ethical principles of a professor. Apart from adopting the basic principles of ethics and accepting a certain system of values consistent with the culture of the environment, it is necessary to pay a constant and great attention to the targeting of deviant elements of existing moral practice - and by doing so, to criticize and eliminate them. Therefore, only by criticizing the existing moral practice, it is possible to make a distinction between the current state and the expected progress. It is desirable to present such a picture through the mobility of teaching staff engaged in higher education in order to obtain, from other advanced scientific and technological environments, a feedback in the form of a model for overcoming the existing unethical elements represented in our university - educational environment. This does not mean that our position, in this case, is significantly more endangered than the position of other regional, European or world universities. Therefore, the affirmative fact is that, in certain segments of higher education, we have models of applying ethical principles in education wich are promising for some countries with higher scientific capacities.

To sum up, we see the mainstream as the most favorable variant of all scientific environments. This is their networking, through the mobility of the teaching chamber where, through unselfish experiential exchanges of the problems about using the code of ethics in education, the higher education systems of the global community can be improved.

\section{CONCLUDING REMARKS}

The paper analyzes the influence of ethics and ISO standards on the education process in higher education. First, the notion of ethics was analyzed, where, from the etymological meaning of the words, through Socrates, Plato and Bentham, a brief historical overview of this phenomenon and its standardized application through history was given. The second chapter examines the process of education and the problem of the ethics of educators, in which, through the proposed use of certain aspects of Plato's eudymonical ethics and the consequentialist ethics of Bentham, a potential improvement of ethical practice in the higher education process was observed. Furthermore, by processing and analyzing MEST EN 15981: 2012 standards of the Institute for Standardization of Montenegro, a channel that can serve as an effective tool for improving ethical practice in the educational process of Montenegrin higher education system was targeted. The aforementioned standard, which refers to the mobility of teaching staff, is presented as an affirmative model for the exchange of experiences of scientific milieus, specifically in the field of setting ethics in education. Overall, the result is a matrix wich has three elements: ethics, education and ISO standard. Based on the set matrix, it has been concluded that progress in the process of education can be enhanced through the synergy of applying ethical principles and corresponding ISO standards. 


\section{BIBLIOGRAPHY}

\section{Books:}

JUKA, S., 2006, Etika - postavke i teorije, FRAM-ZIRAL, Mostar, ISBN 9789958690303

ARISTOTEL, 1988, Nikomahova etika, Globus, Sveučilišna naklada Liber - Zagreb, ISBN 86343-0376-4

LEVINAS, E., 1969, Totality and Infinity, Translated by Alphonso Lingis - Pittsburgh: Duquesne University Press, ISBN 9780820702452 ; ISBN 978-0820702452

PAVİĆEVİĆ, V., 1967, Osnovi etike, Kultura - Beograd, Pergam ID 15120

BENTHAM, J., 2007, An Introduction to the Principles of Morals and Legislation, Courier Corporation, ISBN 04864545259780486454528

\section{Internet links:}

ČOLAKOVIĆ, M., 2010, Filozofija - Sokrat [online], Blogger, http://wwwbloggercomprofile1704280558878.blogspot.com/2010/10/sokrat.html, [Date Accessed: 22 February 2016]

DJORDJEV, B., 2009, Education and Self-learning [online], DESCHOOLING.CLASSROOM $\left(\mathrm{O}^{\wedge} \mathrm{O}\right), \quad$ Belgrade, http://www.deschoolingclassroom.tkh-generator.net/2009/05/17/education-and-selflearning-bojan-djordjevedukacija-i-samo-obrazovanje-bojan-dordev/?lang=HR\#_ftn1, [Date Accessed: 20 March 2019]

DR ŠARAC, 2014, Istorija etike [online], SlideShare - LinkedIn Corporation, http://www.slideshare.net/mdraginaj/istorija-etike, [Date Accessed: 05 February 2016]

DRIVER, J., 2009, Normative Ethics [online], Oxford University Press, http://www.oxfordhandbooks.com/view/10.1093/oxfordhb/9780199234769.001.0001/ oxfordhb-9780199234769-e-2, [Date Accessed: 21 March 2019]

NAILS, DEBRA, 2018, Socrates [online], Stanford Encyclopedia of Philosophy - Stanford University, http://plato.stanford.edu/entries/socrates/, [Date Accessed: 24 January 2016]

TOMIĆ, D., 2016, Aristotelova teorija etike - eudaimonia [online], Učiteljski fakultet Sveučilište $\mathrm{u}$ Zagrebu Odsjek u http://aristotelovateorijaetike.weebly.com/eudaimonia.html, [Date Accessed: 11 February 2016]

URL - 1 Institute for Standardization of Montenegro, 2017, MEST EN 15981:2012 [online], Podgorica - Montenegro, https://www.isme.me/standard/8604, [Date Accessed: 31 October 2018]

URL - 2 Edukuj se, 2019, Šta je hedonizam a šta hedonista - značenje [online], https://www.edukujse.com/sta-je-hedonizam-a-sta-hedonista-znacenje/, Accessed: 20 March 2019]

[Date

URL - 3 Filozofija - seminarski radovi, 2013, Šta je utilitarizam Dž. Stjuart Mil [online], University of Belgrade, https://studenti.rs/skripte/filozofija/sta-je-utilitarizam-dzstjuart-mil/, [Date Accessed: 20 March 2019] 
URL -4 Hrvatski leksikon, 2017, etos značenje [online], Croatia, http://www.hrleksikon.info/definicija/etos.html, [Date Accessed: 16 June 2016]

URL -5 New World Encyclopedia contributors, 2017, Eudaimonism [online], http://www.newworldencyclopedia.org/entry/Eudaimonism, [Date Accessed: 09 October 2017]

URL - 6 The Miroslav Krleža Institute of Lexicography, 2016, Utilitarizam [online], Croatia, http://www.enciklopedija.hr/natuknica.aspx?id=63501, [Date Accessed: 10 April 2016]

WEIJERS, D., 2011, Hedonism [online], Internet Encyclopedia of Philosophy, http://www.iep.utm.edu/hedonism/, [Date Accessed: 13 April 2016] 